\title{
Solar water heating potential in South Africa in dynamic energy market conditions
}

\author{
Georgi Donev ${ }^{\mathrm{a}, \mathrm{b}}$, Wilfried G.J.H.M. van Sark ${ }^{\mathrm{a}, *}$, Kornelis Blok ${ }^{\mathrm{a}}$, Ognjan Dintchev ${ }^{\mathrm{b}}$ \\ a Science, Technology and Society, Copernicus Institute, Utrecht University, Budapestlaan 6, 3584 CD Utrecht, The Netherlands \\ ${ }^{\mathrm{b}}$ Department of Electrical Engineering, Tshwane University of Technology, Staatsartillerie Road, Pretoria West, South Africa
}

\section{A R T I C L E I N F O}

\section{Article history:}

Received 21 July 2011

Accepted 29 January 2012

Available online 22 March 2012

\section{Keywords:}

Solar water heating

Solar thermal

Potential

Scenario

\begin{abstract}
A B S T R A C T
This paper is an attempt to determine the potential for solar water heating ( $\mathrm{SWH}$ ) in South Africa and the prospects for its implementation between 2010 and 2030. It outlines the energy market conditions, the energy requirements related to residential and commercial water heating in the country and the solar water heating market dynamics and challenges. It was estimated that $98 \%$ of the potential is in the residential sector and the rest in the commercial sector. The total thermal demand for 20 years for water heating was estimated to $2.2 \mathrm{EJ}$. A 'Moderate SWH implementation' will provide $0.83 \mathrm{EJ}$ of clean energy until 2030 and estimated cost savings of 231 billion rand. For an 'Accelerated SWH implementation' these figures are $1.3 \mathrm{EJ}$ and 369 billion rand. The estimated accumulated reduction of $\mathrm{CO}_{2}$ emissions due to $\mathrm{SWH}$ can be as high as $297 \mathrm{Mt}$. The increased affordability of residential hot water due to SWH is an important social factor and solar water heating has a strong social effect.
\end{abstract}

(C) 2012 Elsevier Ltd. All rights reserved.

\section{Contents}

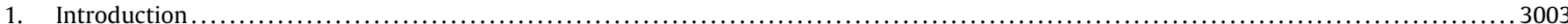

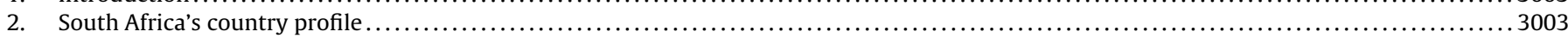

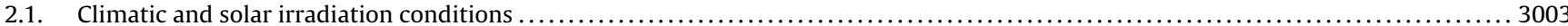

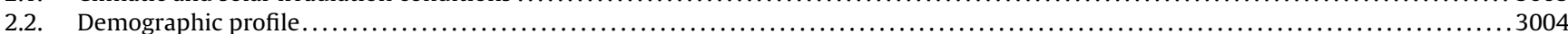

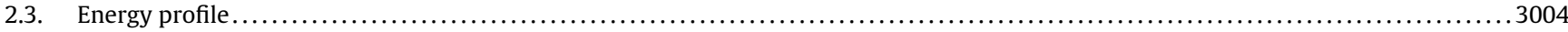

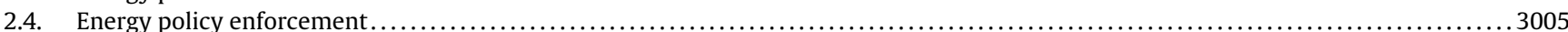

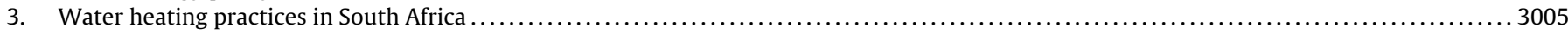

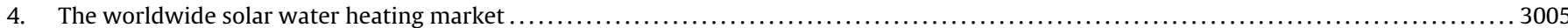

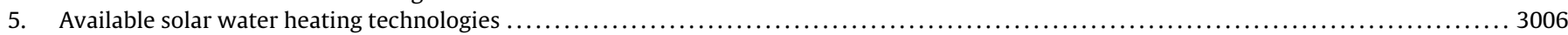

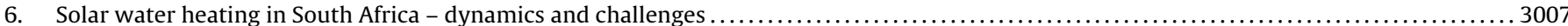

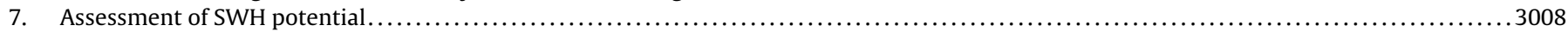

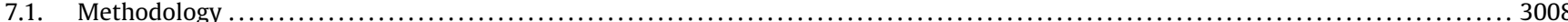

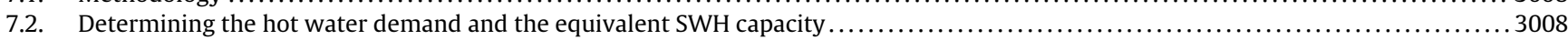

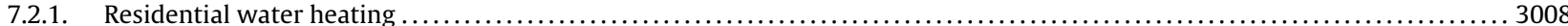

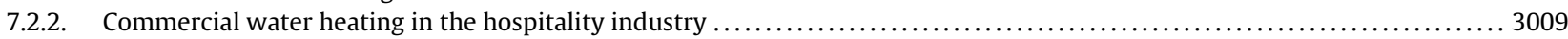

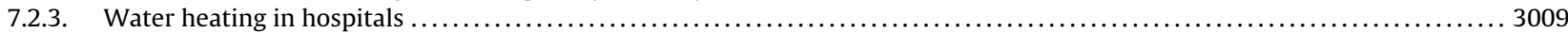

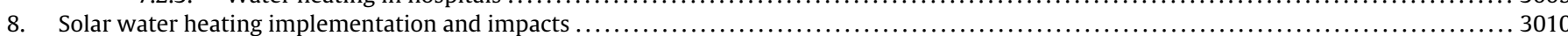

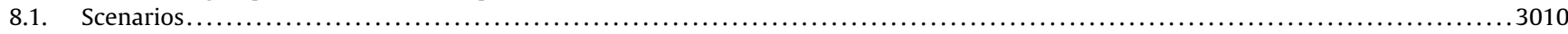

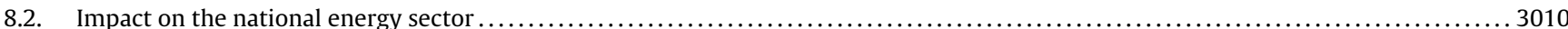

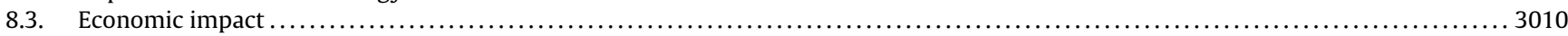

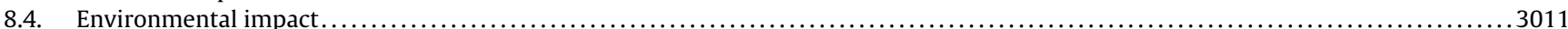

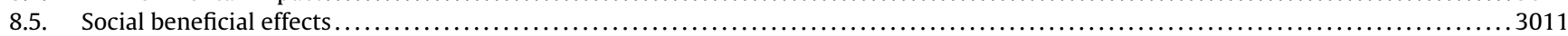

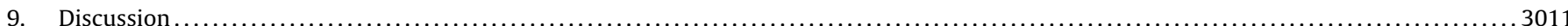

\footnotetext{
* Corresponding author. Tel.: +31 30253 7611; fax: +31 302537601

E-mail address: W.G.J.H.M.vanSark@uu.nl (W.G.J.H.M. van Sark).
} 


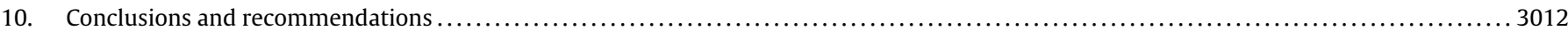

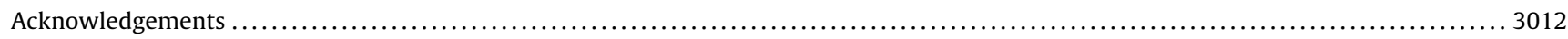

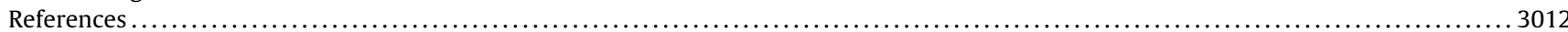

\section{Introduction}

In the last decade South Africa experiences steady economic growth. Large scale housing and electrification programs of the South African Government are underway and they exert pressure on the energy market in the country. The electricity demand in the country grew by 50\% between 1990 and 2007 [1]. In the last 10 years 7.5 billion rand were spent to electrify 2.136 million homes (in this paper we use the following exchange rate: 1 US Dollar $=6.9$ South African rand) [2]. The electricity consumption in the country is experiencing an accelerated growth as is shown in Fig. 1, while generating capacity is about constant around $40 \mathrm{GW}$. The reserve margin of the national electricity grid is reaching $9 \%$ in 2008 after a steady decline from 25\% in 2002 [1]. The International Energy Agency's (IEA) energy balance for South Africa shows a total primary energy supply (TPES) of 127,637 ktoe in 2007 out of which 15,298 ktoe $(12 \%)$ in the residential sector.

The capital expenditure in the electricity generation sector between 2004 and 2008 is 37.5 billion rand. The growing energy demand and strain on the national electricity grid is pressing the South African Government to heavily invest in new generating capacities to meet the growing demand. The approved generation projects amount to 204 billion rand and in addition there are planned transmission projects for 15.5 billion rand and distribution projects for 25 billion rand. The South Africa's electricity public utility ESKOM has an approved construction program for the next two decades for additional $16 \mathrm{GW}$ generating capacity, most of which is from coal-fired plants [1]. This is $40 \%$ increase with respect to present day capacity.

With ever more growing energy demand and the current power deficit in South Africa, the need for utilization of the rich renewable energy resources of the country becomes more obvious and demanding than ever before. With more than 320 sunny days a year in most of South Africa and the current under-use of solar power, a new approach is needed to accelerate the implementation of technologies for solar use [3]. Domestic and commercial water heating requires significant energy resources.

It is clear that in these conditions it is mandatory to look for a new approach to deal with the looming energy crisis in the country. By submitting its pledge following the Copenhagen Accord to take mitigation action for $34 \%$ reduction below the 'business as usual' emissions growth trajectory by 2020 , South Africa recognized the need for limiting the use of fossil fuels such as coal and petroleum products. In its policies the Government is aiming at the establishment and the development of a modern renewable

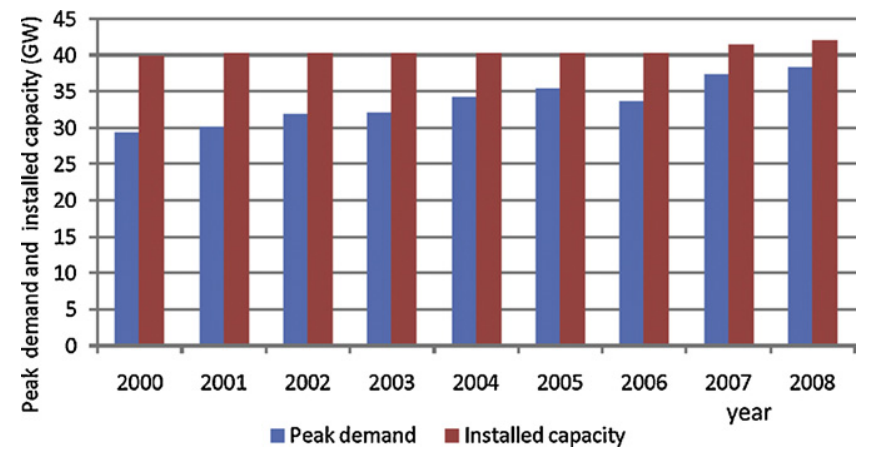

Fig. 1. Peak demand and installed capacity between 2000 and 2008 [1]. energy industry. It must offer in the long run a sustainable, nonsubsidized alternative to fossil fuels. In the South African White Paper on Renewable Energy [4], a medium-term (10 years) target is set to reach $10,000 \mathrm{GWh}(0.8 \mathrm{Mtoe})$ renewable energy contribution to final energy consumption by 2013. Renewable energy is to be utilized for power generation and non-electric technologies such as solar water heating ( $\mathrm{SWH}$ ) and bio-fuels. This target is approximately 4\% (1667 MW) of the projected electricity demand for 2013 $(41,539 \mathrm{MW})[4]$.

So far, the potential for solar energy use as an alternative to fossil fuels remains largely underutilized. Currently around $1 \%$ of South African homes have solar water heaters, despite the favorable geographical and climate conditions [4]. This is presenting a challenging task to further explore the potential and the technology options for accelerated introduction of solar water heating one of the most suitable renewable energy options for the South African conditions.

Similar studies are done in neighbouring countries with similar favorable climatic conditions and similar housing structure Zimbabwe [5] and Namibia [6]. It was found that the potential for solar water heating is mostly identified in the residential sector. In the case of Namibia only $2.4 \%$ of the houses have installed solar water heaters. In Zimbabwe the installed systems are estimated to be below 10,000, including commercial installations in hotels. Furthermore, after analysis of the potential for SWH in that country it was found that $99 \%$ of the total thermal demand is in the domestic sector and hotels and hospitals have insignificant contribution. 98\% of the annual sales in China and $90 \%$ of the sales in the European Union are for the residential sector [7].

This paper is an attempt to investigate the potential for use of solar energy and solar water heating in South Africa in terms of saved energy and emissions. The residential sector, the hospitality industry and the health care institutions are identified as having the highest potential for SWH. The analysis is based on the use of three scenarios to estimate the economic, environmental and social benefits from a large scale implementation of solar water heating in South Africa.

\section{South Africa's country profile}

\subsection{Climatic and solar irradiation conditions}

South Africa occupies the most southern end of the African continent between $22^{\circ}$ and $35^{\circ} \mathrm{S}$ and longitudinally from $17^{\circ}$ to $33^{\circ} \mathrm{E}$. Its surface area is $1,219,090 \mathrm{~km}^{2}$. The climate varies from semiarid in the north-west to sub-tropical along the East coast. The average annual rainfall is $464 \mathrm{~mm}$ - half of the world's average. The warm 'Agulhas' and cold 'Benguela' currents along the East and West coasts respectively have a moderating influence over the climate. The high elevation inland (average $1200 \mathrm{~m}$ above the sea level) keeps the average summer temperatures below $30^{\circ} \mathrm{C}$. In winter, for the same reason, night-time temperatures can drop to the freezing point.

The country's sub-tropical climate is combined with intense solar radiation throughout the year. The African insolation map with different regions differentiated by the value of the annually averaged global solar irradiance is shown in Fig. 2 [8].

In most of the inland regions of the country the irradiation is between 230 and $270 \mathrm{~W} / \mathrm{m}^{2}$ and along the Southern and Eastern coast lines around $180 \mathrm{~W} / \mathrm{m}^{2}$. These insolation levels are 


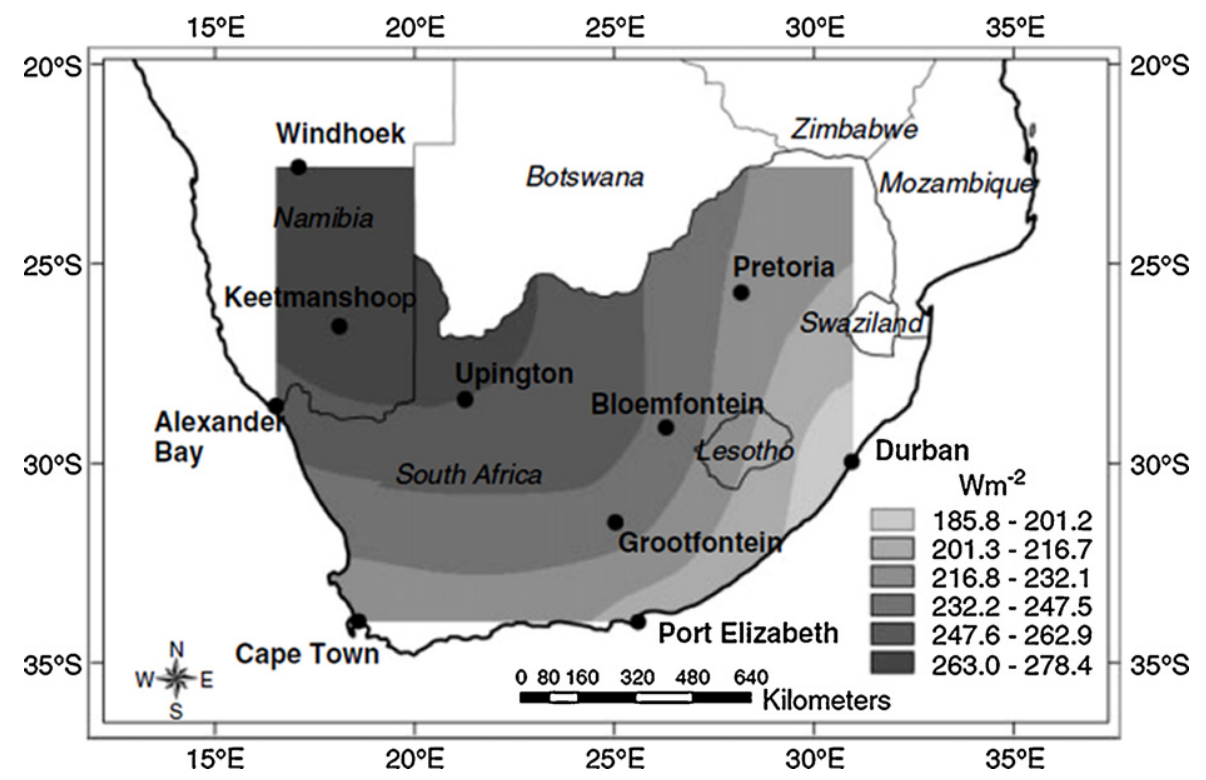

Fig. 2. Annually averaged global irradiance map for South Africa. Power and Mills [8], reprinted with permission.

significantly higher compared to typical levels ranging from $50 \mathrm{~W} / \mathrm{m}^{2}$ and $150 \mathrm{~W} / \mathrm{m}^{2}$ for most of Europe and the United States [8]. The seasonal variations of solar radiation and ambient temperature for the two major regions ('inland' and 'coastal') are shown in Figs. 3 and 4 [9]. The relatively small changes in the average summer and winter irradiance, as well the small ambient temperature seasonal variations present very favourable conditions for solar energy utilization in South Africa. The differences between the inland and

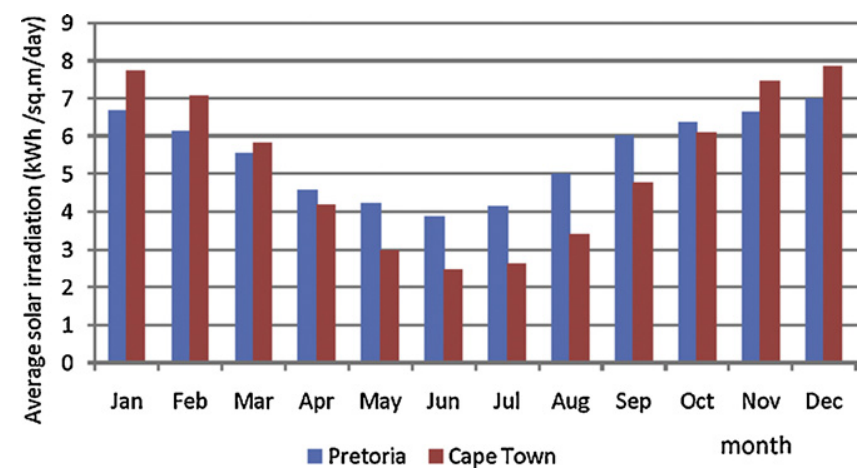

Fig. 3. Monthly average solar irradiation at the regions of Pretoria and Cape Town (data from [9]).

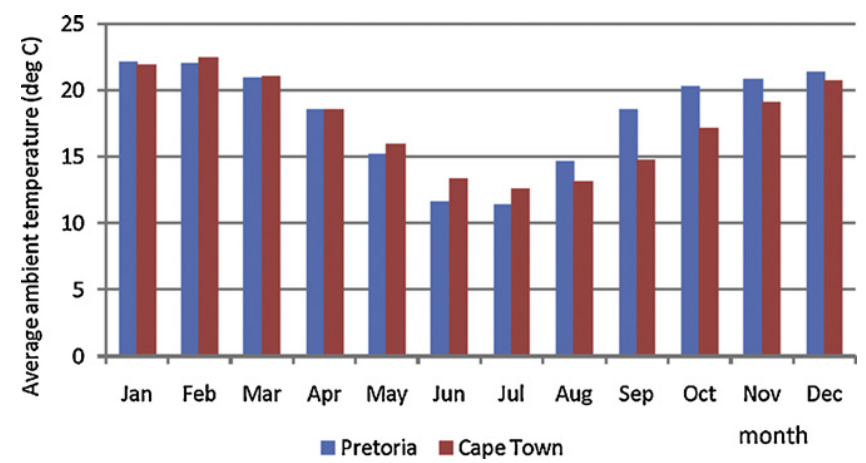

Fig. 4. Monthly average ambient temperatures at the regions of Pretoria and Cape Town (data from [9]). coastal conditions should be taken into account when assessing the potential for solar water heating in the country.

\subsection{Demographic profile}

The population of South Africa is 49.3 million with an annual growth rate of $0.28 \%$ for 2009 . The population density is $40.4 \mathrm{~km}^{-2}$, which is unevenly distributed between the urban and the rural areas. The population is $60.4 \%$ urban and $39.6 \%$ is rural. The total number of households in South Africa is 13.65 million and the average size of the household is 3.61 people $[10,11]$.

\subsection{Energy profile}

South Africa's energy needs are mostly met by coal and oil. Only a small percentage of the energy consumption mix comprises of natural gas, hydro, biomass and nuclear. Coal is mostly used for electricity and synthetic fuel production [12].

The South African energy mix comprises of:

\section{- Oil}

$66 \%$ of South Africa's oil is imported. In 2008, South Africa consumed 575,000 barrels per day (bbl/d) of oil, and imported $380,000 \mathrm{bbl} / \mathrm{d}$ of oil [12]. The rest are locally produced synthetic fuels. South Africa has proven oil reserves of around 20 million barrels in 2010. All of the proven reserves are located offshore southern South Africa in the Bredasdorp basin [12].

\section{- Synthetic fuels}

South Africa has a highly developed synthetic fuels industry supported by abundant coal resources, offshore natural gas and condensate production in Mossel Bay. Natural gas is also imported from Mozambique. The national synthetic fuel manufacturer 'Sasol' has a capacity of $25,438 \mathrm{~m}^{3} /$ day from coalto-liquids (CTL), and 'PetroSA' has a capacity of $7155 \mathrm{~m}^{3} /$ day from gas to liquids (GTL) [12]. The total synthetic fuel production from the two companies provides for approximately $40 \%$ of the South African liquid fuels market. Synthetic fuels account for approximately $76 \%$ of South Africa's oil production.

- Natural gas

South Africa produces only small amounts of natural gas, which it uses in synthetic fuel production. In 2008 South Africa produced 3.257 billion $\mathrm{m}^{3}$, which was all consumed domestically. South 


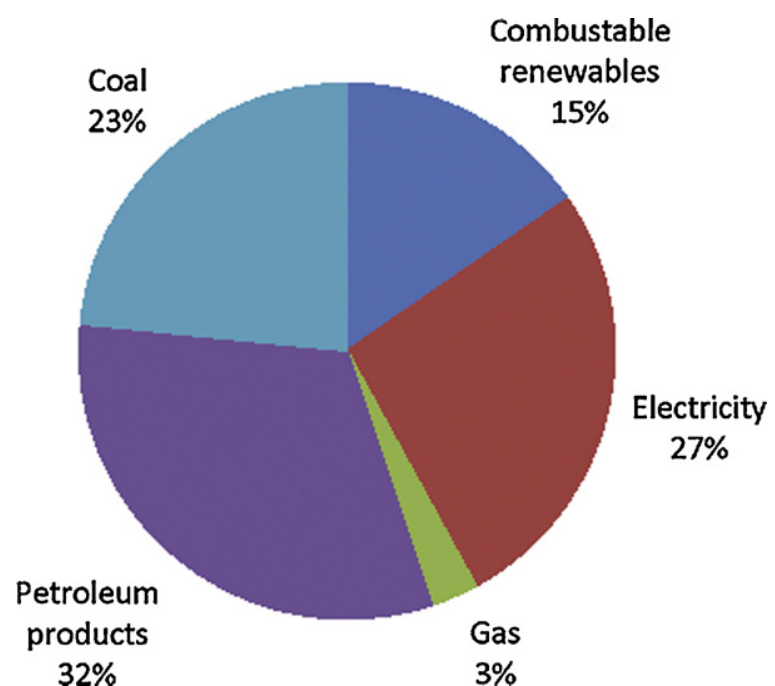

Fig. 5. Distribution of energy consumption in South Africa by type of energy carrier [13].

Africa has gas supply agreements with neighbours Mozambique and Namibia [12].

- Coal

South Africa has the world's fifth largest recoverable coal reserves. The production of hard coal amounts to $247 \mathrm{Mt}$ for 2010 , out of which $67 \mathrm{Mt}$ were exported [13]. Locally the coal is predominantly used for electricity production and for synthetic fuels.

- Nuclear

South Africa has one nuclear power station in the Western Cape, having two units 933 MVA each [1]. It provides for $2.8 \%$ of the energy needs of the country.

\subsection{Energy policy enforcement}

The energy industry of South Africa is regulated by the National Energy Regulator of South Africa (NERSA), established in 2005. South Africa also has a national oil and natural gas company - the 'Petroleum Oil and Gas Corporation of South Africa' (PetroSA). It manages the licensing of oil and natural gas exploration in the country. ESKOM is the national electricity production, transmission and distribution company.

Fig. 5 shows the distribution in the total energy consumption by type of energy carriers and Fig. 6 shows South African energy consumption per sector [13]. South Africa is a significant coal exporter but imports large amounts of oil and some natural gas. The country has a highly developed synthetic fuels industry that uses coal condensate and natural gas as feedstock.

\section{Water heating practices in South Africa}

Residential water heating in South Africa is largely determined by the location and the income category of the houses. $90 \%$ of the urban houses and $42 \%$ of the rural houses do have access to grid electricity [2]. $44 \%$ of the houses have running water connection and $17 \%$ have running water in the area [10]. High income houses are mostly urban, while the low income houses are predominantly rural and in townships located close to bigger cities.

The South African water heating practices are dominated by electrical water heating especially in the urban areas [17]. Around 480,000 electric water heaters are manufactured and installed in the country annually according to a survey by ESKOM [14] with the majority of them (around 75\%) being 150 liter horizontal systems, placed under the roof. The average size of the electrical

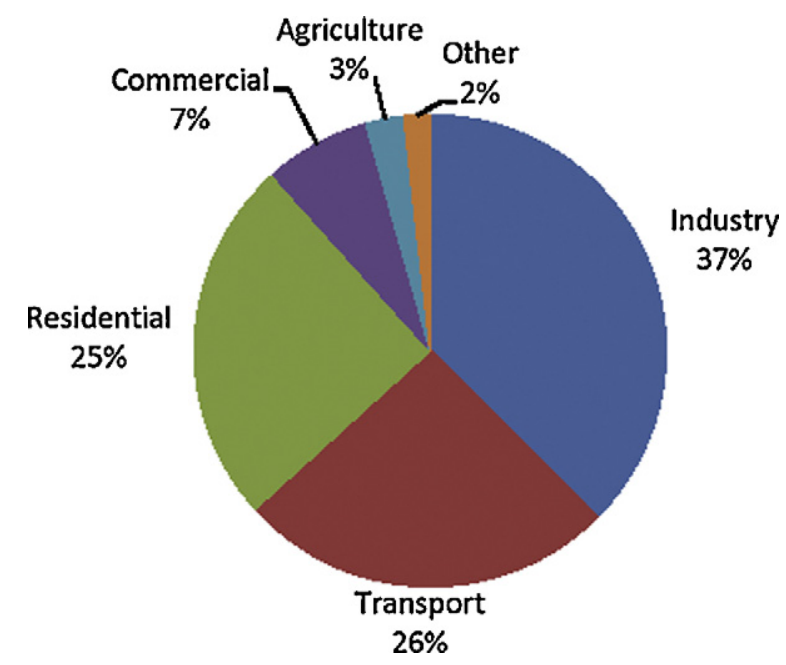

Fig. 6. Distribution of energy consumption in South Africa per sector [13].

element for domestic applications according to the same study is $2.67 \mathrm{~kW}$. According to CEF SWH Project Update Report [14], there are 7,995,246 households with electrical water heaters, which constitute $98.85 \%$ of all water heaters. The rest $(1.15 \%)$ being solar water heaters. On the other hand, in the residential sector, hot water heating accounts for around $40 \%$ of the household energy consumption $[15,16]$. A breakdown of domestic electricity consumption is given in Table 1. Cawood and Morris [19] estimate a saving potential of $70 \%$ through the use of correctly sized solar water heaters with an electrical back-up element, compared with traditional electrical water heaters.

Commercial water heating is done using exclusively large electric storage water heaters. The main loads are hotels, guest houses, resorts, offices, military establishments and hospitals. This is a traditional water heating practice for the last 50 years as a direct result of the traditionally low electricity prices and the availability of electrical supply with good quality and reliability levels. Only recently options for introduction of solar water heating and other renewable options are explored in this sector.

In many low cost housing areas, water heating is done by using paraffin in small quantities and wood. Gas is not popular due to limited availability and its high price.

A study involving 262 low income houses was conducted in Winterveld, a township near Pretoria, in February 2010. The study was done as an effort to quantify the energy savings due to the installation of low pressure solar water heaters low income houses [20]. According to the study the water heating in the audited houses before the installation of the SWH was based on electrical water heaters $-61 \%$, paraffin $-36 \%$, wood $-3 \%$.

\section{The worldwide solar water heating market}

The use of SWH is driven by social, economical and environmental factors for sustainable development both in the industrialized and developing countries. For many communities with limited access to other energy resources, solar water heating can provide a sustainable alternative for improving living standards. It can also have a job creation impact.

Economic sustainability is associated with the lower life cycle costs of solar water heaters, while environmental sustainability is associated with the contribution of SWH for reduction of greenhouse gas emissions from fossil fuel generated electricity. Growth in solar water heating installations worldwide in recent years is $15 \%$ per year [7]. Worldwide more than 260 million square meters $(170 \mathrm{GW}$ th) of solar thermal systems are estimated to be in 
Table 1

A breakdown of domestic electricity consumption for South Africa [16].

\begin{tabular}{|c|c|c|c|c|c|c|}
\hline \multirow[t]{3}{*}{ Types } & \multicolumn{6}{|c|}{ Domestic electricity consumption } \\
\hline & \multicolumn{2}{|l|}{ Up-market } & \multicolumn{2}{|l|}{ Townships } & \multicolumn{2}{|c|}{ Informal settlements } \\
\hline & $\mathrm{kWh} /$ year & $\%$ & kWh/year & $\%$ & $\mathrm{kWh} /$ year & $\%$ \\
\hline Water heating & 2867 & 48.3 & 1345 & 35 & 373 & 18 \\
\hline Cooking & 897 & 15.1 & 1260 & 33.2 & 290 & 14 \\
\hline Space heating & 240 & 4.1 & 73 & 1.9 & 91 & 4.4 \\
\hline Refrigeration & 895 & 15.1 & 429 & 11.3 & 505 & 24.4 \\
\hline Lighting & 677 & 11.4 & 504 & 13.3 & 585 & 28.3 \\
\hline Other appliances & 358 & 6 & 183 & 4.8 & 225 & 10.8 \\
\hline Total & 5934 & 100 & 3794 & 100 & 2069 & 100 \\
\hline
\end{tabular}

Table 2

Solar thermal systems in operation by the end of 2009 (data from [21]).

\begin{tabular}{|c|c|c|c|c|c|c|c|}
\hline \multirow[t]{2}{*}{ Country } & \multicolumn{3}{|c|}{ Water collectors $\left[\times 1000 \mathrm{~m}^{2}\right]$} & \multicolumn{2}{|c|}{ Air collectors $\left[\times 1000 \mathrm{~m}^{2}\right]$} & \multirow{2}{*}{$\begin{array}{l}\text { Total area } \\
{\left[\times 1000 \mathrm{~m}^{2}\right]}\end{array}$} & \multirow{2}{*}{$\begin{array}{l}\text { Total capacity } \\
\mathrm{MW}_{\text {th }}\end{array}$} \\
\hline & Unglazed & Glazed & Evacuated tubes & Unglazed & Glazed & & \\
\hline South Africa & 754 & 288 & 21 & 0 & 0 & 1063 & 745 \\
\hline Israel & 30 & 4039 & 0 & 1 & 0 & 4070 & 2849 \\
\hline Turkey & 0 & 12,035 & 0 & 0 & 0 & 12,035 & 8425 \\
\hline Germany & 720 & 10,727 & 1206 & 0 & 33 & 12,686 & 8881 \\
\hline Switzerland & 222 & 622 & 38 & 859 & 0 & 1741 & 1212 \\
\hline Greece & 0 & 4075 & 3 & 0 & 0 & 4078 & 2854 \\
\hline Austria & 617 & 3634 & 55 & 0 & 0 & 4306 & 3014 \\
\hline USA & 17,794 & 2554 & 88 & 0 & 98 & 20,534 & 14,373 \\
\hline Australia & 4720 & 2444 & 74 & 0 & 0 & 7238 & 5066 \\
\hline China & 0 & 10,150 & 134,850 & 0 & 0 & 145,000 & 101,500 \\
\hline Japan & 0 & 5623 & 98 & 0 & 472 & 6193 & 4335 \\
\hline
\end{tabular}

operation [21]. In Table 2 data for 2009 is shown for the installed solar thermal systems in some countries, including South Africa. Data for the installed solar water heaters in square meters per 1000 inhabitants for some countries is shown in Table 3. It clearly illustrates the low market penetration of solar thermal systems in South Africa despite the favorable solar radiation conditions.

Internationally it can be observed that solar water heating is well developed in countries with relevant Government incentives and policies. For instance, Australia has introduced output related Renewable Energy Certificates with success. As a result of improving government policies in Europe, $5000 \mathrm{GWh}$ of clean thermal energy was generated in 2003 [17]. The major barriers to market penetration are the lack of awareness and the lack of policies to deal with the higher capital costs of solar water heaters compared with conventional electrical storage systems.

\section{Available solar water heating technologies}

A solar water heating system is typically based on three major components - 'solar collector', 'storage tank' and piping for circulation. The 'collector' is a solar heat exchanger, which transfers the collected heat due to solar radiation to circulating water or a low freezing temperature fluid. The heated fluid is then stored in a 'storage tank' that enables a flexible usage pattern for the hot output water - even at night when there is no solar radiation and heat accumulation. There can be another heat exchanger in the storage tank, especially if the heat transfer fluid should be separated from

Table 3

Installed SWH capacity per thousand inhabitants in some countries (data from [21]).

\begin{tabular}{lll}
\hline Country & $\mathrm{m}^{2} / 1000$ inhabitants & $\mathrm{kW}_{\mathrm{th}} / 1000$ inhabitants \\
\hline Israel & 563 & 394 \\
Greece & 379 & 266 \\
Austria & 524 & 367 \\
South Africa & 22 & 15 \\
\hline
\end{tabular}

the outlet water. Such systems are called 'indirect'. The piping enables the flawless circulation between the collector and the storage vessel. The circulation may be natural or pump assisted.

Systems where the collector is directly connected to the storage tank with no piping in between are known as close coupled. These systems are the most common in South Africa.

There are two major types of solar collectors: 'flat plate' and 'evacuated tubes'. In a flat plate collector the absorber is a metal sheet backed by a coil of tubing, through which the heat transferring fluid circulates. The coil-plate assembly is thermally insulated on both sides for minimum heat loss.

Evacuated tubes collector comprise of a number of parallel vertical glass tubes, directly connected to the storage tank. Inside there is an absorber tube covered with selective coating and the air between the inner and the outer tube is evacuated for thermal insulation. Sunlight passes through the outer glass tube and heats the inner one. This technology is relatively new for South Africa and accounts for around 10\% of all collector sales [18]. Other types of SWH systems that have a considerable market share in other countries, like low flow systems, concentrating collectors, integrated collector-tank systems as well as large scale solar thermal arrays have still insignificant market penetration in South Africa. The higher levels of solar irradiation in South Africa are also a factor for slow market penetration of higher efficiency systems. For compensating for lower solar radiation conditions on rainy and cloudy days the storage tanks may have electrical backup heating elements. Glass covered or 'glazed' flat plate collectors are mostly offered on the local market. The share of the different types of solar water heaters on the South African market is shown in Fig. 7 [18].

The share of glazed collectors is rapidly increasing and currently is between $20 \%$ and $30 \%$ of all collectors. It is important to note that unglazed collectors are mostly used for domestic swimming pools [18]. It must be noted also that electric swimming pool water heating installations are only typical for commercial swimming pools found in upmarket hotels, resorts and gyms. 


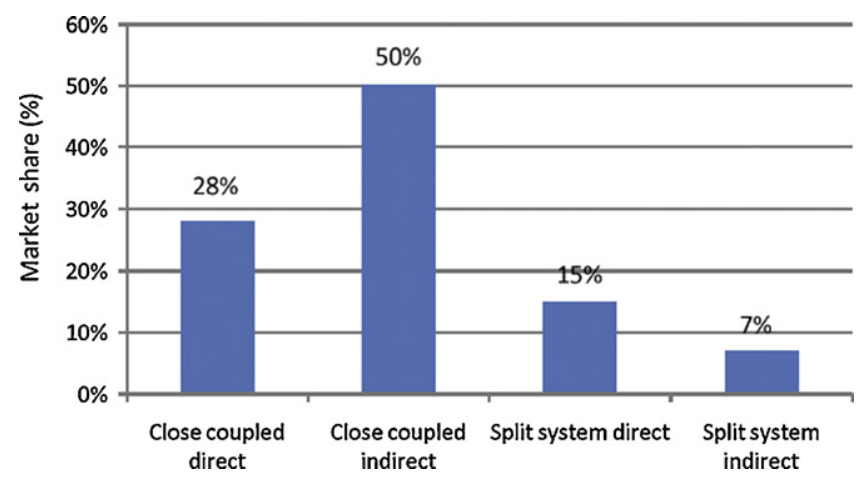

Fig. 7. Market share of direct and indirect systems [18].

\section{Solar water heating in South Africa - dynamics and challenges}

Market surveys for SWH were conducted for the Department of Minerals and Energy (DME) in 2002 [19] and the Energy Development Corporation (EDC) of the Central Energy Fund (CEF) in 2005 [17]. The survey done in 2002 [19] shows a steady growth of solar water heaters sales between 1975 and 1985, reaching $27,500 \mathrm{~m}^{2}$ delivered systems annually, of which around $85 \%$ were unglazed, mostly installed on swimming pools. In the late eighties there was a $47 \%$ decline in sales due to problems with quality of the installed systems and the increased affordability of electrical water heating. The market only recovered in the recent years in line with the changed conditions in the local energy market and the emerging electricity crisis in the country. A more recent study of the South African solar water heating market was conducted in 2009 for ESKOM Distribution [18]. The annual sales figures for the solar water heating systems delivered on the South African market between 1991 and 2009 are given in Fig. 8 and the systems with glazed and unglazed collectors are shown separately. No consistent data is registered between 1995 and 2000 by any of the surveys. A sharp increase of around $72 \%$ of total number of sales between 2005 and 2008 can be observed as compared to previous periods [18,19,22]. An introduction of solar water heating technologies like evacuated tubes that were new for the country and significant quality improvements of existing types were also registered. The tendency of steady growth in sales continued in 2009 following the initiation of a number of market supporting programs run by ESKOM, CEF and some municipalities.

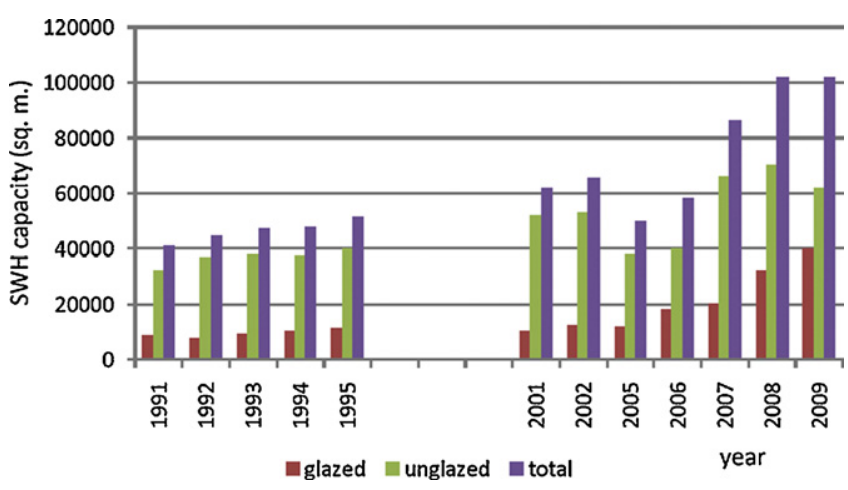

Fig. 8. Annual SWH sales figures for South Africa between 1991 and 2009 (data from Refs. [17-19]).

Despite the encouraging trends in the recent years, a combination of different factors determines the low market penetration of solar water heaters in South Africa:

- Lack of SWH awareness

Previous research efforts and surveys point out the lack of awareness for the negative environmental impacts of electrical water heating and for the benefits of utilizing the potential of SWH to reduce energy bills and promote sustainable and efficient usage of energy and water in South Africa [17,20,23]. The electrical generating and distributing utilities underestimate the potential of the SWHs to reduce the peak demand and energy consumption in the domestic and commercial sectors. The potential for job creation by expanding the SWH market is also often underestimated [23].

- Relatively low electricity prices in South Africa

South African domestic electricity prices are nearly half of the electricity price in most of the world countries as can be seen in Fig. 9 [24]. The quality of supply has also been good. The relatively low electricity prices have been increased lately by $37 \%$ compared to 2006 levels, due to high coal prices and the need for large investments in the national electricity generation and transmission sector.

- Undeveloped renewable energy national policies

South Africa has not adopted yet legislation to facilitate the expansion of the SWH technology. The 'White Paper for Renewable Energies' is a promising framework for future Government policies promoting renewable energy use. The South African Government has set a target for renewable energy to contribute

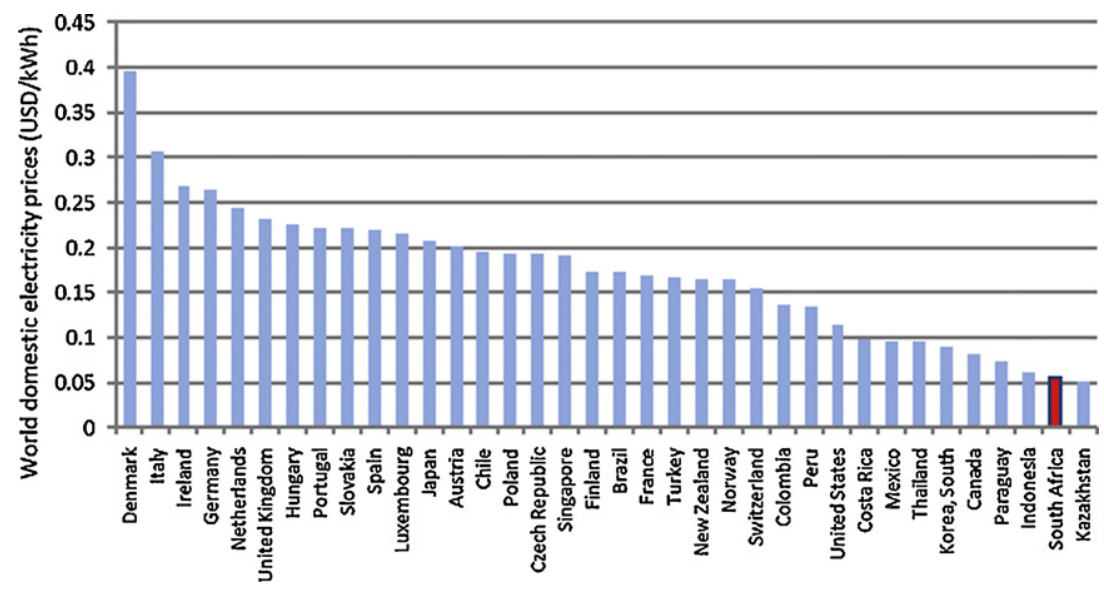

Fig. 9. Comparison of world domestic electricity prices in 2008 (data taken from [24]). 
$10,000 \mathrm{GWh}$ of final energy consumption by 2013. Macroeconomic studies done by the Department of Minerals and Energy (DME) estimated that up to $23 \%$ of this target could be contributed by solar water heating [4].

- Lack of training for SWH installation and maintenance

Training in installation and maintenance of SWH is practically non-existent in a larger scale. Some SWH manufacturers offer it as part of their product support but as whole it is not properly organized and guided.

- Technical constraints

South African Standards for thermal performance of domestic SWH systems make provision for outdoor and indoor testing [25-28]. For the performance of solar collectors currently international standard ISO 9459-1 is used [29]. These standards are not mandatory and many of the local and imported products are not tested according to them. Furthermore, there are no South African standards for testing of solar collectors, which has a major negative impact on promoting quality control and performance excellence among local manufacturers of solar collectors. Testing and certification of local SWH products is a pre-requisite for the promotion of SWH technology in South Africa and market development.

- Limited running water connections in many low income areas

According to Statistics - South Africa [10], in 1996, only 3.977 million households in the country did have running water connections and 0.442 million had a borehole connection suitable for installation of solar water heating system. This is $48.7 \%$ of all 9.06 million households in the country, which further limits the possibilities for installing SWHs in many residential areas.

- High initial cost of the solar water heating systems

A major limiting factor for the implementation of solar water heating is the relatively high initial cost of solar water heating systems. According to a recent survey of South African SWH industry [14], and updated price lists of the major manufacturers and importers, the average price per square meter is 4191 rand, including installation costs. This figure is beyond the affordability level for most of the low-income households.

\section{Assessment of SWH potential}

\subsection{Methodology}

The potential for solar water heating will be determined as the technical potential that is likely to be implemented in the country, taking into account various limitations and incentive factors [29].

The residential water heating demand in the country is determined separately for high income and low income houses, due to differences in the hot water consumption patterns and quantities. Further the required solar thermal replacement power for meeting the same hot water demand will be determined. The costs for water heating using the current techniques and their projected estimates then will be evaluated and compared to the costs for introduction of solar water heating systems.

The thermal demand for water heating in hotels and guest houses is determined according to the number of bed-nights for the country and the hot water consumption per occupant per day. In a similar way the thermal load in hospitals is determined, taking into account the total number of beds, the occupancy rate and the specific hot water consumption per bed for health institutions. The potential effect is then evaluated for its additional social and environmental benefits.

The reference levels for determining the potential for domestic solar water heating are essential part of the analysis and will be referred to three future scenarios - 'Business as usual (BAU)', 'Moderate SWH implementation' and 'Accelerated SWH implementation' $[30,31]$.

\subsection{Determining the hot water demand and the equivalent SWH} capacity

\subsubsection{Residential water heating}

The approach used to determine the hot water demand in households depends on the type of the household and the availability of electrical connection to it. For these reasons, in similar efforts to determine the household thermal demand [32], the households are categorized according to the energy mix for water heating and taking into account hot water consumption. Households in the current study are split into two major groups - urban and rural. Most of the urban houses are electrified and do have water connection. The income levels there are higher than in rural areas, which leads to higher hot water demand. Further, the urban dwellings are subdivided in high income and low income. The estimated average daily hot water demand at $60^{\circ} \mathrm{C}$ for high income urban houses is $60 \mathrm{l} /$ person per day; for low income urban houses this is $30 \mathrm{l} /$ person per day and for rural areas with limited water supply and low income levels this figure is even lower at 201/person per day.

In urban high income homes more than $98 \%$ of the heating is done by electrical water heaters (EWH) that potentially can be replaced by SWH systems. The remaining $2 \%$ the water heating is done by using liquefied petroleum gas (LPG) heaters that can also be replaced by $\mathrm{SWH}$.

In low income urban areas the hot water demand is determined using different energy mix including electricity, wood fuel and paraffin. The percentage share of each of them as well as the water consumption is based on the study at the Wintersveld township. The domestic electricity consumption is studied in previous research attempts [14-16] where the residential electricity load and its distribution including water heating is evaluated.

In rural areas availability of grid electricity plays an important role for determining the fuel mix for water heating. The changes in the energy profiles, following the electrification in five rural villages were studied by Madubansi and Shackleton [33]. The results showed that after electrification, the percentage of households using only wood for heating is decreasing only by $1 \%$ (from $45 \%$ to $44 \%$ ) and only $1.4 \%$ is the share of electricity only for thermal applications. Even less is the use of paraffin only for water heating $-0.8 \%$. In such houses the water consumption is also limited due to supply constrains and affordability. In the UNEP study [32] an average of $15 \mathrm{~kg}$ of wood fuel and 0.11 of paraffin per day per household was determined. In most of the households a mixture of different energy sources is used for water heating. Based on data from several studies in urban areas [16], in five rural villages [33] and in Winterveld township [20] we estimate the shares of water heating practices as shown in Fig. 10.

The thermal demand for residential water heating, $E_{R H W D}$ then will be determined, following the approach of Batidzirai et al. [5]:

$E_{R H W D}=\sum_{i} W_{i} \cdot P_{i} \cdot c_{p} \cdot \Delta T \cdot \eta_{p i}$

where $W_{i}$ is the hot water demand per person per year in group $i$, $P_{i}$ is the number of persons in group $i$ according to location and the specific water heating technology, $c_{p}$ is the specific heat capacity of water $(4.19 \mathrm{~kJ} /(\mathrm{kg} \mathrm{K})), \Delta T$ is the difference in temperatures between the hot water output and the inlet water and $\eta_{p i}$ is the efficiency of the specific hot water heating process. For these calculations $\Delta T$ is taken as the average temperature difference between outlet hot water $\left(60^{\circ} \mathrm{C}\right)$ and inlet cold water in summer and in winter. According to a research done in several locations in the Gauteng province the summer water inlet temperature is $19^{\circ} \mathrm{C}$ and during the winter is $9^{\circ} \mathrm{C}$. The average annual difference between these two values is $46^{\circ} \mathrm{C}$. The efficiencies of a hot water storage heater, 


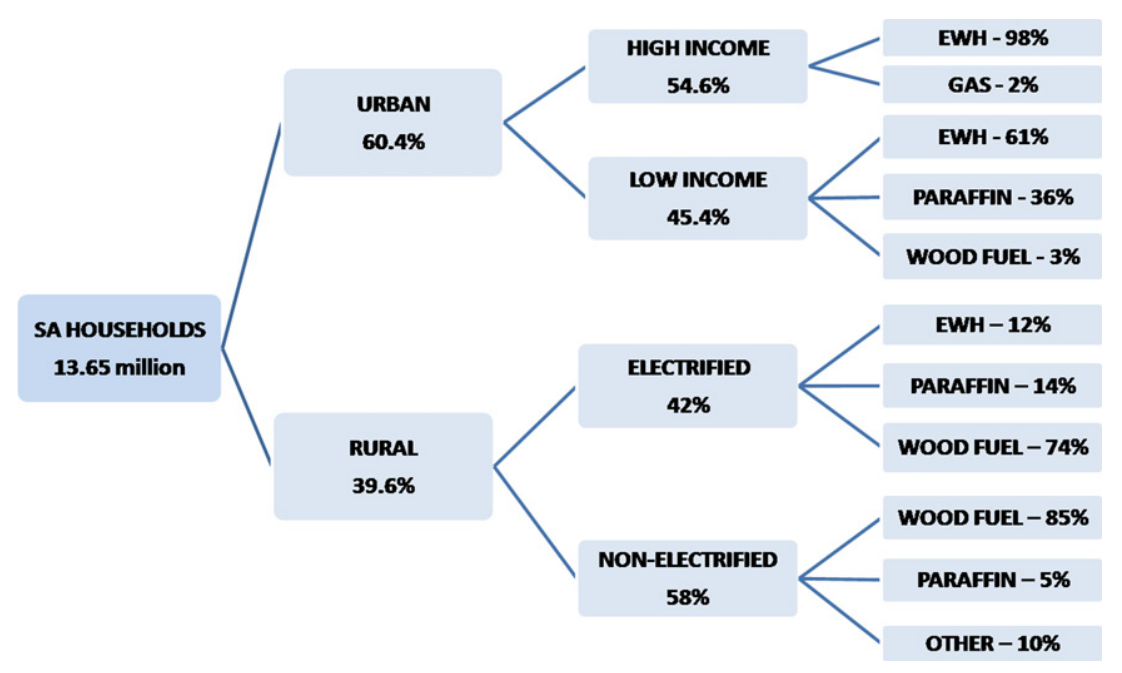

Fig. 10. Current domestic hot water usage patterns in different households in South Africa.

electric plate, paraffin heater and wood burning stove are taken: $0.9,0.65,0.4$ and 0.25 respectively $[5,34]$.

\subsubsection{Commercial water heating in the hospitality industry}

The South African hospitality industry uses mostly electrical water heaters and only an insignificant number of accommodation establishments are using alternative technologies. This industry produced $8.8 \%$ of the country's GDP in 2005 and this figure is expected to increase to $12 \%$ by 2014 . The occupancy rate is low and unsteady at $6.4 \%$. A total of 128 million bed-nights are recorded by the National Accommodation Association of South Africa for 2009 [35]. This indicator is used to determine the thermal load. The hot water consumption per guest per day is estimated at 110 laccording to industry standards. The thermal demand for commercial water heating, $E_{C H W D}$ then will be determined by:

$E_{C H W D}=\sum W_{g} \cdot \mathrm{BN} \cdot c_{p} \cdot \Delta T \cdot \eta_{e}$

where $W_{g}$ is the hot water consumption per guest per day, BN is the number of 'bed-nights' per year, $c_{p}$ is the specific heat capacity of water $(4.19 \mathrm{~kJ} /(\mathrm{kg} \mathrm{K})), \Delta T$ is the difference in temperatures between the hot water output and the inlet water and $\eta_{e}$ is the efficiency of electric water heater set at 0.9 .

\subsubsection{Water heating in hospitals}

The hot water load in hospitals is determined in a similar way. There are 157,238 hospital beds in private and state hospitals in South Africa. The average occupancy rate is around $80 \%$. The water heating in hospitals is done exclusively by using large electrical storage water heaters. The hot water consumption is $150 \mathrm{l} /$ bed per day. The thermal load for water heating in hospitals, $E_{H H W D}$, can be determined then as:

$E_{H H W D}=\sum W_{b} \cdot B \cdot r \cdot c_{p} \cdot \Delta T \cdot \eta_{e}$

where $W_{b}$ is hot water consumption per bed per day, $B$ is number of beds and $r$ is the average annual occupancy rate.

The total thermal requirement for the residential, the commercial and the hospital sectors is:

$E_{H W D}=E_{R H W D}+E_{C H W D}+E_{H H W D}$

The equivalent SWH capacity [30] in $\mathrm{m}^{2}$ is determined from the hot water demand $E_{H W D}$ by Eq. (5):

$S_{S W H D}=\frac{E_{H W D} \cdot f_{S O L}}{\eta_{S O L} \cdot G}$ where $f_{\text {sol }}$ is the solar fraction for SHW systems with electrical back-up element, $\eta_{S O L}$ is an average solar water heating system's efficiency, which for the typical flat plate type systems is around 0.65 and $G$ is the mean yearly solar radiation, which for South Africa is $2057 \mathrm{kWh} /\left(\mathrm{m}^{2}\right.$ year $)$.

SWH systems installed in up-market urban areas are having electric back-up elements to compensate for reduced solar radiation levels and increased hot water demand. According to Cawood and Morris in the 'Baseline study - solar energy in South Africa' [19], the solar fraction $\left(f_{\text {sol }}\right)$ of such electrically backed - up systems is close to $70 \%$. In low income urban houses and in rural houses the installed SWH do not have electric back-up elements and it is considered that all the required heat will be solar produced.

The annual thermal demand for water heating by different technologies and its projected growth between 2010 and 2030 according to the applied model is shown in Figs. 11 and 12.

From these figures, it is clear that the use of electricity for water heating will continue to grow steadily, following population growth trends during the next 20 years [11]. The enhanced availability of electricity in rural areas will also be a contributing factor [33] and by the end of the 20-year period the projected annual thermal demand for electrical water heating will reach close to $100 \mathrm{PJ}$ - a growth of $28.8 \%$ compared to current levels. Clearly, electricity remains the prime source for water heating. The share of paraffin and wood used for water heating will follow similar trend and will increase to $6.49 \mathrm{PJ}$ and $7.34 \mathrm{PJ}$ respectively, which can only in part be contributed to population growth factors. The projected increase of the share of other energy sources like dung and crops off-cuts will

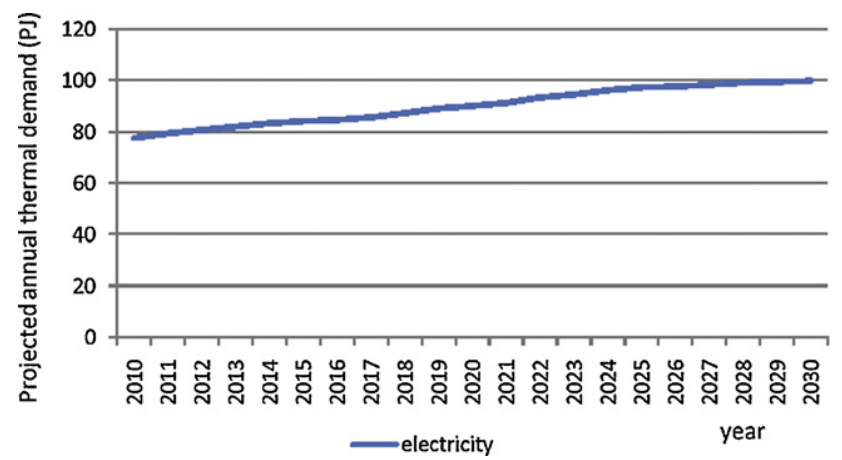

Fig. 11. Projected annual thermal demand for electrical water heating between 2010 and 2030. 


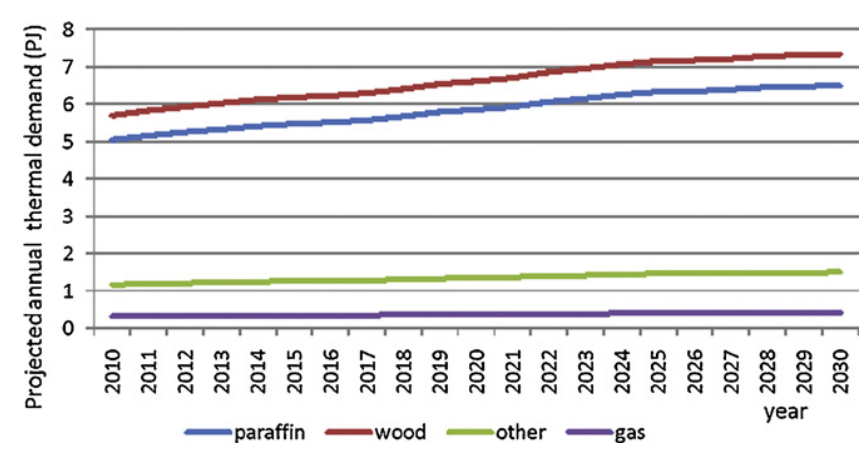

Fig. 12. Projected annual thermal demand for water heating by other sources between 2010 and 2030.

grow insignificantly. The use of gas will remain on the current levels due to high prices and limited availability.

\section{Solar water heating implementation and impacts}

\subsection{Scenarios}

The prospects for different rates of solar water heating implementation are evaluated taking into account historical trends and the changing conditions on the South African energy market [36]. The practical potential for the development of solar water heating on a wider scale in the country is estimated according to three scenarios - 'Business as usual' (BAU), 'Moderate SWH implementation' and 'Accelerated SWH implementation'. These scenarios are investigating the impact on the energy balance for a 20 -year period (from year 2010 till year 2030). The first scenario assumes that the residential hot water requirements in the country will be met by only using the current energy mix. The diffusion of solar water heaters will remain on the current minimal level of $1.15 \%$ of the households. The second scenario is describing a moderate implementation of SWH in 2030, where 50\% of the SWH market potential will be achieved and the third one - an accelerated implementation of SWH in 2030 , where a higher $80 \%$ of the market potential will be achieved. These scenarios are taking into account a few limiting factors that are determining the practical potential of implementation of solar water heating:

- Currently only $48 \%$ of the rural houses are having access to running water on the premises, which limits the amount of hot water usage.

- The South African solar water heating industry currently is capable of supplying about $200,000 \mathrm{~m}^{2}$ per year both from local production and imports. It can be expected that the share of the imported systems can and will grow. Between 2007 and 2009 the number of imported systems has increased from $4500 \mathrm{~m}^{2}$ to almost $14,000 \mathrm{~m}^{2}[18]$.

- The market saturation is also to be accounted for. The level of saturation can depend on consumer purchasing power; as well as competition, prices, and technology development. The purchasing power can be determined by:

$C_{t}=C(1+i)^{-t}$

where $C_{t}$ is the future purchasing power in $t$ years, $C$ is the purchasing power in today's money and $i$ is the inflation rate. It is unlikely to see in the next 20 years a technological breakthrough as competition to SWH and the other existing methods for water heating. Through technology development as well as increased deployment though [37], it can be expected that prices of SWH systems can become more affordable.

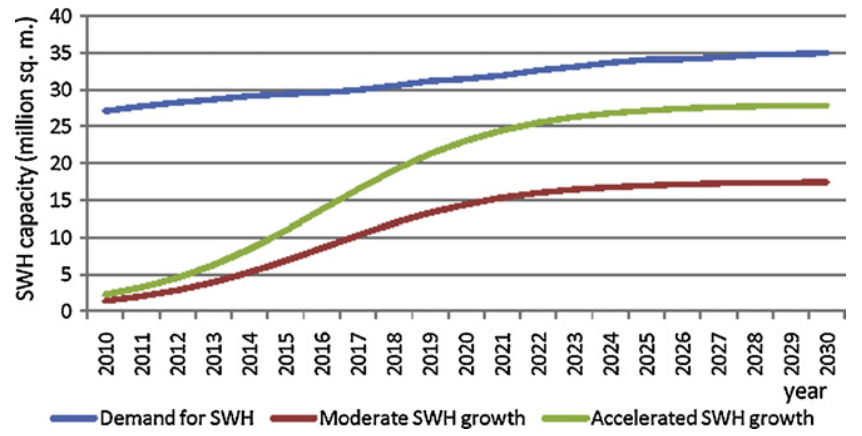

Fig. 13. Moderate and accelerated SWH implementation scenarios compared to the SWH demand.

The cumulative number of installations during the studied period until 2030 can be modelled using a logistic function:

$S(t)=\frac{S_{A} \cdot S_{0} \cdot e^{r t}}{S_{A}+S_{0}\left(e^{r t}-1\right)}$

where $S(t)$ is the cumulative number of installed solar water heaters, $r$ is the market growth rate, $S_{A}$ is the market saturation level, $S_{0}$ is the market's initial number of installed solar water heaters in the first year of the studied period. The market growth rate is proportional to both the initial number of installations and the conditions and available resources to sustain the growth rate. In the beginning of the studied period a faster growth rate of $\mathrm{SWH}$ sales is expected due to the initiation of several SWH incentive programs with the support of ESKOM and some municipalities. The results from applying the scenarios for solar water heating implementation till 2030 are given in Fig. 13.

\subsection{Impact on the national energy sector}

The projected impact of different levels of solar water heating diffusion according to the different scenarios can be evaluated by the total amount of energy saved as a result of the implementation of solar water heating between 2010 and 2030, see Table 4. The results in Table 4 are split for different water heating patterns. The efficiencies of the conversion process are already incorporated in the used model. For a more complete picture, as far as the electrical water heating is concerned, the transmission and distribution losses should also be taken into account. For South Africa they are $6.1 \%$ on average. Since $88 \%$ of the electrical energy in South Africa is generated in coal-fired power stations, the average efficiency of $39 \%$ of the conversion process must also be considered. The figures for the estimated energy shifted from electrical water heating to solar thermal under the different scenarios should be increased according to:

$E_{E L(C O A L)}^{\prime}=\frac{\left(k_{\text {coal }}+k_{\text {coal }} \cdot k_{\text {loss }}\right) \cdot E_{E L}}{\eta_{\text {th }}}$

where $k_{\text {coal }}$ is the fraction of electricity produced in coal-fired power stations, $k_{\text {loss }}$ is the transmission and distribution loss co-efficient, $\eta_{t h}$ is the average thermal efficiency of coal-fired power stations in the country and $E_{E L}$ is the energy that can be shifted from electric water heating to solar water heating. In this way the primary energy requirement for the energy shifted to $\mathrm{SWH}$ will be $1834.8 \mathrm{PJ}$ under the 'Moderate SWH' scenario and 2929.9 PJ under the 'Accelerated SWH' scenario respectively.

\subsection{Economic impact}

The cost benefits from the implementation of SWH can be determined using life cycle costing method. The net present value is 
Table 4

Estimated energy shifted to SWH between 2010 and 2030.

\begin{tabular}{|c|c|c|c|c|c|c|c|c|c|}
\hline & \multicolumn{6}{|c|}{ Residential } & \multirow{2}{*}{$\begin{array}{l}\text { Commercial } \\
\text { Electrical } \\
\text { PJ }\end{array}$} & \multirow{2}{*}{$\begin{array}{l}\text { Total Electrical } \\
\text { PJ }\end{array}$} & \multirow{2}{*}{$\begin{array}{l}\text { Total } \\
\text { PJ }\end{array}$} \\
\hline & $\begin{array}{l}\text { Electrical } \\
\mathrm{PJ}\end{array}$ & $\begin{array}{l}\text { Paraffin } \\
\text { PJ }\end{array}$ & $\begin{array}{l}\text { Wood } \\
\text { PJ }\end{array}$ & $\begin{array}{l}\text { Gas } \\
\text { PJ }\end{array}$ & $\begin{array}{l}\text { Other } \\
\text { PJ }\end{array}$ & $\begin{array}{l}\text { Total } \\
\text { PJ }\end{array}$ & & & \\
\hline Thermal demand (WH) & 1866.9 & 122.9 & 138.9 & 28.3 & 7.7 & 2164.6 & 43.3 & 1910.2 & 2207.9 \\
\hline BAU & 21.5 & 1.4 & 1.6 & 0.3 & 0.1 & 24.9 & 0.9 & 22.4 & 25.8 \\
\hline Moderate SWH & 701.9 & 46.2 & 52.2 & 10.6 & 0.3 & 811.2 & 18.9 & 720.8 & 830 \\
\hline Accelerated SWH & 1123 & 73.9 & 83.5 & 17 & 4.6 & 1302.1 & 26 & 1149 & 1328 \\
\hline
\end{tabular}

Table 5

Estimated cumulative $\mathrm{CO}_{2}$ emission savings in mega tonnes under the different scenarios.

\begin{tabular}{|c|c|c|c|c|c|c|c|c|}
\hline \multirow[t]{2}{*}{$\mathrm{CO}_{2}$ emissions } & \multicolumn{6}{|l|}{ Residential } & \multirow{2}{*}{$\begin{array}{l}\text { Commercial } \\
\text { Electrical } \\
\text { Mt }\end{array}$} & \multirow{2}{*}{$\begin{array}{l}\text { Total } \\
\text { Mt }\end{array}$} \\
\hline & $\begin{array}{l}\text { Electrical } \\
\text { Mt }\end{array}$ & $\begin{array}{l}\text { Paraffin } \\
\text { Mt }\end{array}$ & $\begin{array}{l}\text { Wood } \\
\text { Mt }\end{array}$ & $\begin{array}{l}\text { Gas } \\
\text { Mt }\end{array}$ & $\begin{array}{l}\text { Other } \\
\text { Mt }\end{array}$ & $\begin{array}{l}\text { Total } \\
\text { Mt }\end{array}$ & & \\
\hline BAU & 5.3 & 0.1 & 0.2 & 0.02 & 0.009 & 5.6 & 0.2 & 5.8 \\
\hline Moderate SWH & 172.0 & 3.4 & 5.9 & 0.6 & 0.03 & 181.8 & 4.6 & 186.4 \\
\hline Accelerated SWH & 275.1 & 5.4 & 9.4 & 1.0 & 0.5 & 291.3 & 6.4 & 297.7 \\
\hline
\end{tabular}

defined as the sum of present inflows and outflows for each year of the life cycle of the equipment:

$N P V=\sum_{t=1}^{n} \frac{R_{t}}{(1+i)^{t}}$

where $t$ is the time of the cash flow, $n$ is the life cycle, and $i$ is the discount rate. An appropriate discount rate is $10 \%$ (a social discount rate for a similar study [5]) and $R_{t}$ is the net cash flow (the amount of cash, inflow minus outflow) at time $t$. The costs are calculated for the starting year of this study, i.e. 2010. The life cycle of solar water heating systems is equal to the period for which this study is done: 20 years.

The estimated cost savings due to energy required for water heating, which is shifted to SWH is 230.8 billion rand for the 'Moderate SWH implementation' and 369.2 billion rand for the 'Accelerated SWH implementation'. Under the 'Business as usual' scenario these savings are estimated to be only 1.4 billion rand.

\subsection{Environmental impact}

The potential energy savings due to introduction of $\mathrm{SWH}$, presented in Table 4, can be used to estimate the positive environmental impact of this technology. The results for the potentially saved emissions from shifting the hot water load to $\mathrm{SWH}$, using the IPCC emission factors [38,39], are shown in Table 5. Clearly, 94\% of the emission savings are attributed to replacement of electrical load to SWH. Also $97 \%$ of the saved carbon emissions are originating from the residential water heating shifted to solar.

Apart from the direct emission reduction, the implementation of SWH can also have other environmental benefits like reduced water consumption in the power generating sector and less land lost for coal mining and generating stations.

\subsection{Social beneficial effects}

With $57 \%$ of the population in South Africa living below the poverty line [40], the affordability of residential hot water in adequate quantities is an important social factor. According to the study in the Winterfeld township [20], the estimated hot water consumption was as low as $10.5 \mathrm{l} /$ person per day. With the installation of low pressure solar water heaters without electrical back up, the hot water consumption rose to 19.81 /person per day. In low income areas, solar water heating has strong social effect for improving the quality of living of many. It will also contribute towards achieving the Millennium Development Goals to ensure environmental sustainability. In UNDP MDP Country Report for 2010 [41], it is stated that South Africa has produced 434 mega tons of $\mathrm{CO}_{2}$ in 2007 and it is aiming at reduction by $30 \%$ in the next 5 years.

The electricity savings from the use of electrically backed-up SWH can reach $30 \%$ of the monthly electricity expenses or around $130 \mathrm{kWh}$ a month per household. With the current average municipal electricity price of $0.9 / \mathrm{rand} / \mathrm{kWh}$, and an average initial cost of a typical domestic water heater of 14,000 rand, the pay-back period is estimated to 7.5 years. This figure can vary with the different hot water consumption patterns. Taking into account the favorable climatic conditions in South Africa, the average payback period is longer than the commonly accepted payback periods of up to 5 years in other countries [3,42].

The solar water heating industry is rapidly growing in South Africa. In 2007 only 21 companies were registered as SWH manufacturers and suppliers. In 2009 this number has doubled. It is established by recent surveys [18] that over 700 people are employed in the solar water industry in $2009,57 \%$ of them as installers. With the current size of the SWH industry the employment opportunities can increase in the next few years by $40 \%$.

\section{Discussion}

Since the potential for SWH and its impacts on the energy balance of the country and the environment is estimated in this study for comparatively long future period, the scenarios used and the assumptions made do not provide for corrective feedback to the inputs. An important assumption was made that the period of 20 years is going to be one of steady economic and demographic growth [36]. The analysis is based on the assumption that SWH diffusion is following a logistic function. The function can no longer be representative if during the studied period there will be sharp changes in any of the input conditions. The announced current sharp increase of the electricity prices by $35 \%$ annually for the last 3 years, for example, can be viewed as an accelerating factor for the diffusion rate. The latest study of the SWH market in 2009 [18] shows a growth of $72 \%$ a year.

The surveys done in the recent years are mostly documenting the domestic market for solar water heating. For the commercial sector there is very limited information about the number of installations, the types of the systems, etc. The thermal demand estimation could only be based on average hot water consumption figures, number of beds and occupancy rates. Seasonal occupancy rate variations are not included in the analysis. The Government 
subsidy programs do not include commercial installations and these installations are not reliably documented.

The awareness about the benefits of SWH is growing in the country in line with Government subsidy programs and different educational programs. Direct subsidies to consumers are offered in the range between 2200 and 7500 rand for the typical domestic solar water heaters. The Government programs are managed and implemented by CEF, ESKOM and some municipalities.

The introduction of SWH on a large scale in the country will also have a positive effect on the maximum demand of the electrical supply system. This effect is difficult to quantify, because of the diversity of the water heating process and the hot water consumption patterns. In this regard the programs for ripple control of electrical storage water heaters, currently running in many municipalities, are a valuable supplementing measure in the attempts to reduce the peak electrical load.

\section{Conclusions and recommendations}

The current study shows that there is realistic and significant potential for SWH in South Africa. The climatic conditions and the available solar irradiation are amongst the most favourable in the world. Due to low electricity prices for the last few decades, electrical water heating has become standard for all the high and medium income households. Only in low income areas other water heating technologies are used.

A number of reasons were identified for the low implementation levels of SWH in South Africa. Apart from the relatively low electricity prices, can be noted the non-mandatory character of the relevant quality standards, the undeveloped policies for renewable energy promotion and the still undergoing efforts for providing running water supply to many residential areas.

The potential was estimated for the residential and the commercial sector separately and it was found that only $2 \%$ of the potential is in the hotels and hospitals and the rest is in the residential sector. The total thermal demand for 20 years for water heating was estimated to $2.2 \mathrm{EJ}$. If $50 \%$ of this demand is met by SWH this will provide $0.83 \mathrm{EJ}$ of clean energy until 2030. For the more optimistic $80 \%$ target this figure will be $1.328 \mathrm{EJ}$. The study has established the energy mix for water heating for different types of households and this information can be used to evaluate the impact of solar water heating not only on the national grid but on the wider energy market in the country. The potential share of the electrical energy to be shifted to solar thermal is $85.3 \%$ of the energy mix. The estimated cost savings from the implementation of SWH in the residential and commercial sectors are 230.8 billion rand for the 'Moderate SWH implementation' and 369.2 billion rand for the 'Accelerated SWH implementation'. Under the 'Business as usual' scenario these savings are estimated to only 1.4 billion rand.

The SWH technology and the prospects of its implementation in the country have significant environmental effect as well. An estimated reduction of $186.4 \mathrm{Mt} \mathrm{CO}_{2}$ emissions for the moderate SWH scenario and $297.7 \mathrm{Mt}$ for the accelerated SWH scenario can be expected. These numbers are substantial compared to the present $434 \mathrm{Mt} \mathrm{CO}_{2}$ emissions in South Africa [41].

The required solar water heating capacity is calculated in million square meters of collector area. For the "Moderate SWH implementation' scenario, there is potential for 17.39 million $\mathrm{m}^{2}$ over 20 years and for the 'Accelerated SWH implementation' scenario the projected installed area is 27.82 million $\mathrm{m}^{2}$. These industry challenging figures are compared to the current size of the solar water industry in the country, which can supply around $200,000 \mathrm{~m}^{2}$ annually. In its current state and size, the industry can supply only $23 \%$ of the required quantities for the 'Moderate SWH implementation scenario and $14.4 \%$ of the 'Accelerated SWH implementation' quantities. Since currently only $58 \%$ of the installed systems are locally manufactured [18], there is a strong potential for industry growth with positive effect on the economy and on the employment rate. Further, it is important to note that a large scale implementation of this clean technology will ensure significant increase of the amounts of hot water availability for household purposes in low income areas, up to twice the current levels.

The following recommendations can be made to facilitate the success of the ongoing SWH technology promotion:

- There is a need for a much more pro-active approach for creating awareness for the benefits of SWH. Currently such awareness enhancing programs are run by ESKOM and some municipalities. Most of the available educational information and promotion materials are available for the wide public only on line or in specialized publications, to which the large percentage of the population has limited access. There is a need for more close to the community awareness campaigns, including leaflets, demonstrations and pilot projects to promote the benefits of $\mathrm{SWH}$.

- The existing policies for SWH promotion and implementation should be revised and improved. For the success of such efforts an efficient feedback system should established, supported by the Government, for regular updating the available information concerning the SWH market not only for the residential sector, but for the commercial sector as well. Subsidies and tax relief schemes as options can be explored for commercial installations.

- The South African SWH industry should be supported for accelerated growth. A valuable help could be provided by Government supported programs for training installers. They will be very effective especially in remote areas, far for from the major solar industry manufacturers, who currently are having the potential and the resources to promote this clean technology.

- A valuable contribution to the growth of the South African SWH market could be provided by implementing innovative and successful policies, adopted in other countries, including local tax relieves for households using $\mathrm{SWH}$. The suitability of such policies for the South African conditions has not been established yet and this could be viewed as a worthy challenge for future research efforts.

\section{Acknowledgements}

We would gratefully like to thank D. Holm and B. Bredenkamp (CEF) for their help to acquire data for the solar water heating market in South Africa in the recent years as well as NUFFIC (Netherlands Organization for International Cooperation in Higher Education) for the financial support under contract NPT/ZAF/247 (Enhancing Tshwane University of Technology (TUT) Capacity for Research and Postgraduate Training in Electric Power and Industrial Systems) and establishing a Centre for Energy and Electric Power (CEEP) at TUT.

\section{References}

[1] Maroga J. Update on state of power security in South Africa. Johannesburg: ESKOM; 2008.

[2] World business council for sustainable development. ESKOM electrification program for South Africa, www.wbcsa.org; 2010.

[3] Clean Energy Project Analysis. RETScreen International. ISBN 0-622-35674-8; 2004. p. SWH7.

[4] DME. White Paper for the Promotion of Renewable Energies and Clean Development, Pretoria; 2003.

[5] Batidzirai B, Lysen EH, van Egmont S, van Sark WGJHM. Potential for solar water heating in Zimbabwe. Renewable and Sustainable Energy Reviews 2009;13:567-82.

[6] Emcon, UNDP. Assessment of feasibility for the replacement of electrical water heaters with solar water heaters - Final Report, Windhoek; 2005. 
[7] Maithel S, Modi S, Ameen M, Bhanware P. Solar water heaters in India: market assessment studies and surveys for different sectors and demand segments. Greentech; 2010.

[8] Power HC, Mills DM. Solar radiation climate change over Southern Africa and assessment of the radiative impact of volcanic eruptions. International Journal of Climatology 2005;25:295-318.

[9] NASA Atmospheric Sciences Data Center. www.eosweb.larc.nasa.gov.

[10] Statistics South Africa. www.statssa.gov.za/census01/census96/../Households.

[11] Van Aardt. Population and household projections for South Africa by province and population group, BMR UNISA; 2007.

[12] EIA. South Africa energy data, statistics and analysis - oil, gas, electricity, coal; 2010.

[13] IEA. World energy statistics, energy balances of non-OECD countries; 2010.

[14] Central Energy Fund Solar Water Heating Project Update, ETA, CEF, Johannesburg; March 2010.

[15] Holm D, Holm H, Lane IE, Van Tonder C. Local Integrated Resource Planning Project Hartbeerspoort. University of Pretoria; 1999.

[16] Geldenhuys A. ESKOM Domestic Load Research; 1998.

[17] Holm D. Market Survey of Solar Water Heating in South Africa for the Energy Development Corporation (EDC) of the Central Energy Fund (CEF), Pretoria; 2005.

[18] The South African Solar Water Heater Industry, ESKOM, Distribution; August 2009.

[19] Cawood WN, Morris G. Baseline study - solar energy in South Africa 2000-2001, Report prepared for DANCED; 2002.

[20] Donev GS, Dintchev OD. Winterveld SWH project, unpublished data; 2010.

[21] Weiss W, Mauthner F. Solar heat worldwide, market and contribution to the energy supply 2009. SHC International Energy Agency; 2011.

[22] ESKOM Solar water heating monthly status report, ESKOM, Distribution; October 2009.

[23] Dintchev OD. Solar water heating in South Africa. Environmental Impacts Constrains and Prospective, DUE Cape Town; 2005.

[24] EIA. Electricity Prices for Households; June 2010.

[25] Dintchev OD, Motsumi M. Performance tests in standards compliance for solar water heating projects, DUE Cape Town; 2007.
[26] South African Standard SANS 6211-2:2003: Domestic solar water heaters. Part 1. Thermal performance using an outdoor test method.

[27] South African Standard SANS 6211-2:2003: Domestic solar water heaters. Part 2. Thermal performance using an indoor test method.

[28] South African Standard SANS 10106:2005: The installation, maintenance, repair and replacement of domestic solar water heating systems.

[29] International Standard ISO 9806-1: Test Methods for Solar Collectors International Standard ISO 9459-1: Solar Heating - Domestic Water Heating Systems.

[30] Blok K. Introduction to energy analysis. Amsterdam: Techne Press; 2007.

[31] Hoogwijk M. On the global and regional potential of renewable energy sources. PhD thesis. Utrecht University; 2004.

[32] Maya RS, Nziramasanga N, Muguti E, Fenhann J. UNEP greenhouse gas abatement costing studies. Zimbabwe country study. Phase II. Zimbabwe: Southern Centre for Energy \& Environment, Riso National Laboratory, Department of Energy; 1993.

[33] Madubansi M, Shackleton CM. Changing energy profiles and consumption patterns following electrification in five rural villages in South Africa. Energy Policy 2006;34:4081-92.

[34] Davis M, Horvei T. Handbook for the economic analysis of energy projects. Development Bank of Southern Africa/DMEA/Eskom; 1995.

[35] National Accommodation Association of South Africa, www.naa-sa.org.

[36] Schipper L, Meyers S. Using scenarios to explore future energy demand in industrialized countries. Energy Policy 1993;21:264-75.

[37] Junginger M, Van Sark W, Faaij A, editors. Technological learning in the energy sector. Cheltenham, UK: Edward Elgar; 2010.

[38] The Intergovernmental Panel on Climate Change (IPCC) emission factors at http://www.ipcc-nggip.iges.or.jp.

[39] UNFCCC (United Nations Framework Convention on Climate Change), retrieved from the World Wide Web, http://maindb.unfccc.int/public/ country.pl?country=ZA; April 2009.

[40] HSCR. Fact Sheet Poverty South Africa, http://www.sarpn.org.za.

[41] UNDP. Millennium Development Goals, Country Report 2010, South Africa.

[42] Energy Efficiency Policies around the World: Review and Evaluation, www.worldenergy.org/publications. 